\title{
EDITORIAL:
}

\section{KEKUASAAN NARATIF (NARRATIVE POWER) DALAM HUBUNGAN INTERNASIONAL}

Pada masa dunia dilanda krisis global yang disebabkan oleh bencana alam (seperti wabah penyakit menular, gelombang tinggi pasang laut Tsunami) maupun bencana yang disebabkan oleh ulah manusia (seperti peperangan antarnegara, aksi-aksi teroris internasional), negara-negara dan para pelaku internasional lainnya sudah tentu akan berusaha untuk mengatasi krisis dan memulihkan keadaan. Dalam situasi krisis yang serba tidak menentu dan terbatas ini, isu-isu baru dapat muncul mengenai apa, bagaimana serta mengapa dan siapa yang paling bertanggungjawab yang dikomunikasikan melalui narasi-narasi yang kerap mengarah kepada adu narasi (battle of narrative). Negara-negara sebagai institusi yang memiliki otoritas dalam hubungan internasional dapat memanfaatkan momentum ini untuk mengukuhkan dan memastikan kekuasaannya di dunia melalui kekuatan naratif.

Untuk memahami proses politik pada hubungan internasional dalam memanfaatkan kekuasaan naratif di saat krisis global dapat diamati pada masa dunia dilanda krisis pandemi Virus Corona-19 (Covid-19) sejak akhir Desember 2019. Dalam upaya mencegah dan mengatasi ancaman virus ini di wilayah masing-masing negara, muncul isu belum tersedianya obat atau vaksin penyembuh, dan cara-cara dalam menekan daya penularan penyakit, serta siapa yang paling bertanggung jawab atas penyebarannya. Isu global pandemi Covid-19 kemudian menjadi wacana yang dinarasikan di sepanjang waktu melalui diplomasi dan ragam media massa/publik baru masa kini ke seluruh dunia. Tiongkok dan Amerika Serikat (AS) tampak sebagai negara terkemuka dalam adu narasi yang tercipta dari krisis Covid-19. Narasi-narasi kedua negara ini menurut Chang 
(2020), di satu sisi ditujukan untuk mempersatukan negara-negara bekerjasa sama dalam mengatasi pandemi, di sisi lainnya untuk mempersamakan persepsi mereka tentang siapa yang lebih pantas dalam memegang kendali tatanan dunia

Target utama dari narasi-narasi pada masa pandemi 2020 sudah tentu lebih banyak ditujukan kepada Tiongkok sebagai negara yang salah satu wilayahnya (Kota Wuhan) pertama kali terjangkit virus menular Covid-19. Namun Tiongkok dapat pula memanfaatkan tantangan ini dengan melancarkan kekuatan naratifnya sendiri. Narasi-narasi Tiongkok dipertunjukkan mengenai kesiapan dan kesigapan pemerintah di bawah kepemimpin Xi Jin Ping dalam bentuk kebijakan-kebijakan dan implementasinya untuk menekan penyebaran penyakit dan mengurangi jumlah korban. Di awali dengan narasi deklarasi resmi Tiongkok mengenai wabah Covid-19 di Wuhan, kebijakan isolasi lokal, dan aksi kemampuan Tiongkok membangun rumah sakit besar dalam waktu satu minggu pada masa virus menjangkit. Ketika masa pandemi di negaranya tampak mereda narasi Tiongkok memperlihatkan kebijakan dan aksi ketulusan membantu negara-negara lain yang terjangkit, seperti Iran dan Serbia, dengan mengirim obat-obatan, masker, perawat, tenaga medis dan sebagainya. Tiongkok juga melancarkan narasi-narasi untuk meyakinkan negaranegara lain guna menjadi lokasi uji coba vaksin Sinovac yang diproduksinya. Di sisi yang lain, Tiongkok pun melancarkan narasi-narasi yang membantah tuduhan Amerika dan melakukan kontra tuduhan mengenai asal terjadinya Covid-19. Pertunjukan narasi-narasi Tiongkok ini dimaknai oleh banyak pengamat sebagai upaya Tiongkok untuk membangun kepercayaan dan perhatian dunia, membangun dominasi wacana dalam memperkenalkan sub-tatanan dari tatanan kekuasaan atau kepemimpinan dunia yang berlaku maupun kemugkinan menggantinya pada pasca pandemi (Chang, 2020).

Pada posisi yang berlawanan Amerika Serikat (AS) di bawah kepemimpinan Donald Trump, sebagai salah negara terbanyak korban penyakit Covid-19 juga melancarkan narasi-narasi untuk memastikan status-quo kepemimpinan globalnya. Dengan semangat mengambil preseden dari beberapa keberhasilan kekuasaan naratif pemerintah AS dalam politik dunia, seperti narasinarasi AS yang membenarkan perangnya melawan teror setelah serangan teroris 11 September 2001, dan kemenangannya dalam 'pertempuran naratif' dengan ISIS, selain pertempuran militer yang dilancarkannya di Suriah dan Irak (Engel, 2016). AS berusaha mematahkan perluasan kekuasaan dominasi dan naratif Tiongkok pada masa pandemi melalui narasi-narasi Presiden Donald Trump yang menempatkan Tiongkok sebagai pihak yang bersalah namun dengan cara 
yang arogan dan rasisme. Narasi Trump ini tidak didukung oleh fakta yang menunjukkan keberhasilan nyata dari kebijakan dan aksi AS dalam menangani pandemi. Oleh karena itu AS tidak mendapatkan simpati dan dukungan publik nasional dan internasional, dan bahkan AS mengalami penurunan kemampuan kepemimpinan dunia terutama dalam kerja sama global untuk mengatasi pandemi.

Pandemi Covid-19 jelas bukan yang pertama atau terburuk yang menyebabkan krisis global dan adu narasi antarnegara. Aktor politik di seluruh dunia mungkin selalu mengandalkan narasi untuk tujuan komunikasi, tetapi dalam beberapa tahun terakhir mereka tampaknya semakin sadar akan kekuatan bernarasi dalam politik internasional. Fenomena semacam ini pernah terjadi di lingkup global ketika Perang Dingin berlangsung antara kubu Barat yang dipimpin oleh Amerika Serikat dan kubu Timur yang dipimpin oleh Uni Soviet dengan implikasi yang luar biasa bagi pergeseran tatanan dunia. Pada saat itu perang lebih banyak ditunjukkan melalui adu narasi ideologis ketimbang perang fisik dengan persenjataan militer yang telah mereka persiapkan. Di lingkup regional adu narasi yang belum sepenuhnya berakhir terjadi antara Jepang dan negaranegara bekas jajahannya di Asia mengenai sejarah bersama dan klaim identitas Jepang sebagai negara pasifis (Gustafsson \& Hanssen, 2019). Di lingkup nasional perang narasi melalui media antara Rusia dan beberapa media negara Barat pada masa krisis yang terjadi di antara Rusia dan (Hutchings \& Szostek, 2015). Di lingkup transnasional, kelompok teroris berbasis agama, seperti ISIS, telah menebar narasi yang meyakinkan kepada pengikut lintas bangsa yang direkrut bahwa demi agama melakukan kekejaman adalah sah. Di lingkup ruang maya yang tak berbatas pada masa era pascamodern dan pasca-kebenaran (post struth) yang difasilitasi oleh Revolusi Industri 4.0 narasi dan kontra narasi politik hadir dengan cepat yang tidak didasarkan lagi oleh fakta melainkan oleh sentimen dan kepercayaan. Narasi-narasi politik semakin masif menunjukkan keampuhannya sebagai perangkat kelancaran kebijakan maupun sebagai senjata dalam menjatuhkan lawan melambungkan diri dan memenangkan sesuatu tujuan. Apakah kemajuan dalam pertarungan naratif dipahami sebagai 'diplomasi publik', 'soft power', 'propaganda' atau 'perang informasi' sangat bergantung pada seberapa baik narasi yang berbeda beresonansi dengan hati dan pikiran penonton di seluruh dunia.

Narasi-narasi, seperti yang dikatakan oleh Hagstron dan Gustafsson (2019) dipelajari melalui naratologi, yaitu studi yang hirau dengan bentuk cerita atau dongeng yang menekankan alur dasar yang sama dan mengandung elemen yang serupa. Pengguna naratologi pada awalnya 
adalah para ahli sastra untuk mengkaji teks-teks sastra, kemudian para ahli sejarah dalam merangkai kejadian-kejadian yang tersebar menjadi cerita yang bermakna dengan plot (Hagström \& Gustafsson, 2019, p. 389). Kurangnya karakteristik positivisme dari naratologi menyebabkan skeptisisme para ahli ilmu-ilmu sosial lainnya yang berkecenderungan positivistik untuk memperhatikan narasi. Kemudian baru diterima ketika feminisme dan aliran pos-pos memberi kesadaran bahwa narasi-narasi bukan hanya sekedar teks, rangkaian atau struktur kronologis teks atau cerita belaka tanpa makna atau dengan makna yang bebas nilai dan natural. Melainkan narasi memberikan makna pada apa yang terjadi, bagaimana, di mana, kapan dan mengapa itu terjadi dan siapa protagonisnya melalui metode inklusi dan eksklusi, pilihan leksikal, manipulasi perbedaan relasional yang berhubungan dengan identitas. Oleh karena itu semua narasi adalah konstruksi pemaknaan yang bersifat politis dan subjektif, dan wadah kontestasi intersubjektif kepentingan para konstruktor atau narator. Sebuah narasi, bagaimanapun, dicirikan oleh struktur cerita kronologis, mulai dari awal, tengah dan biasanya berakhir dengan pesan-pesan subjektif berbalut mitos yang memberikan pelajaran untuk masa depan dan saran tentang kebijakan mana yang masuk akal dan realistis untuk diadopsi dan didukung (Hagström \& Gustafsson, 2019, pp. 389391). Oleh karena itu narasi lebih persuasif dan bersifat ajakan daripada argumen analitis statistik positivistik karena orang-orang terserap di dalamnya. Melalui penyerapan dan penerimaan mereka atas makna dan pesan naritif sebagai 'akal sehat' inilah kemudian narasi menjadi dominan atau tersingkir. Bila persuasi erat kaitannya dengan kapasitas untuk menghasilkan efek maknawi dan memobilisasi tindakan kolektif, dan kapasitas ini berkaitan makna kekuasaan (power), maka narasi adalah suatu bentuk kekuasaan (power) tersendiri.

Kekuasaan naratif para pelaku internasional di arena internasional pada abad ke-21 semakin terlihat secara verbal maupun nir-verbal melalui ragam medium di dunia nyata maupun dunia maya. Meskipun demikian narasi tetap menjadi konsep yang belum dieksplorasi dalam disiplin Hubungan Internasional (HI). Narrative turn yang menyusul linguistic turn telah lama diproklamasikan dalam ilmu-ilmu sosial tetapi gaungnya tidak memiliki dampak abadi pada HI. Sejak 1990-an terdapat beberapa pakar studi HI yang hirau mengenai narasi sebagai bentuk cerita dan narasi sebagai bentuk kekuasaan walau dengan pemaknaan yang saling berbeda dan dengan sudut pandang yang berbeda pula. Di antaranya adalah Erick Ringmar (1996) dan Hidemi Suganami (2008) sebagai pelopor dalam membuka wawasan berbasis narasi-narasi sebagai cara untuk memahami dunia dan sebagai instrumen kekuasaan antarnegara. 
Dalam studi HI 'kekuasaan' biasanya didefinisikan sebagai kepemilikan kemampuan yang nyata dan dapat dihitung dan dianalisis melalui pengukuran agregat peralatan dan pengeluaran militer, produktivitas ekonomi, ukuran populasi dan wilayah (Morgenthau, 1948). Melalui pemahaman mengenai kekuasaan naratif, definisi ini dapat disingkap merupakan suatu bentuk narasi persuasif untuk membuat pihak lain percaya bahwa negara yang berkuasa itu adalah yang memiliki sumber-sumber material seperti yang disebut oleh Morgenthau. Narasi dengan pemahaman sebagai instrumen persuasif pada dasarnya dapat membuat, membentuk, dan mengubah dunia, termasuk memengaruhi cara memandang proses politik dan mengubah hubungan kekuasaan di hubungan internasional. Narasi-narasi memengaruhi cara aktor sebagai negara, jenis bangsa dan individu memandang dirinya sendiri. Narasi-narasi itu juga memposisikan aktor di dalam suatu struktur kekuasaan dalam tatanan politik global.

Membicarakan mengenai makna kekuasaan atau power dalam studi HI tidak lah mudah meskipun kekuasaan merupakan konsep, teori dan praktik yang mengemuka di dalam arena politik dunia. Seperti yang dikatakan oleh Robert Gilpin (1981), konsep kekuasaan tidak mudah didefinisikan, sulit dan mengganggu. Selain itu, istilah power yang berasal dari bahasa Inggris tidak mudah diterjemahkan ke dalam bahasa Indonesia secara baku sebagai kekuasaan karena kandungan maknanya yang beragam. Makna power mencakup beberapa makna, seperti kekuasaan (power), kekuatan atau daya paksa (forces), pengaruh (influence), wewenang atau otoritas (authority), kemampuan (ability) dan kapabilitas (capability). Selain itu seperti yang dikenalkan oleh Allen (1999) power juga mengandung makna dominasi (power over), pemberdayaan (power to), power within. Tipologi dari power juga diperdebatkan antara hard power dan soft power, maupun smart power (Nye J. S., 2012). Selain itu power juga dilihat sebagai suatu bentuk kepemilikan, perilaku, relasi maupun tujuan. Meskipun demikian para ahli teori kekuasaan sepakat bahwa kekuasaan sebagai kapasitas untuk menghasilkan efek, namun tidak setuju tentang apakah agen atau struktur lebih penting dalam memproduksinya. Oleh karena itu sampai kini tidak adanya kesepakatan tunggal atas definisi konsep power atau kekuasaan itu di dalam studi HI.

Arus utama Hubungan Internasional belum mampu mengintegrasikan perkembangan penting dalam konsepsi kekuasaan sejak publikasi Steven Lukes's "Power: a Radikal View" (1974). Lukes berbicara mengenai relasi kekuasaan (power relations) dalam politik internasional yang terdiri dari tiga lapis dimensi atau wajah (three dimension of power atau three faces of power). Dimensi pertama fokusnya adalah pada pelaksanaan kekuasaan sesaat dalam hubungan sebab 
akibat langsung antara dua atau lebih agen atau pihak, seperti yang diungkapkan dalam pernyataan para Weberian seperti Robert Dahl (1961), Keohane dan Nye, Jr. (1977) bahwa kekuasaan adalah kemampuan A untuk membuat B melakukan sesuatu yang tidak akan dilakukannya sebaliknya. Di sini kekuasaan bersifat power over atau dominasi dan represif yang biasanya didukung pelaksanaannya oleh kemampuan sumberdaya yang mencakup kekuatan material dan fisik (persenjataan militer dan ekonomi) serta otoritas politik (Lukes, 1974: 14).

Dimensi power kedua, yang didasarkan oleh teori power dari Peter Bachrach and Morton Baratz (1962) yang menekankan pada aspek strukrural dari kekuasaan, yaitu kekuasaan dapat dilaksanakan bahkan ketika A tidak menyadari pengaruhnya terhadap B. Kekuasaan dalam pengertian ini adalah kemampuan untuk membentuk dan mengontrol agenda politik (agenda setting) melalui pengaturan kelembagaan, mobilisasi bias, sehingga membungkam perbedaan pendapat dan membatasi pilihan dengan mencegah isu dan alternatif memasuki debat publik (Lukes, 1974: 16).

Dimensi yang ketiga, ditawarkan oleh Lukes sendiri berdasarkan definisi Gramscian, mengacu pada aspek epistemik atau kognitif dari kekuatan, yaitu A dapat menjalankan kekuasaan atas B dengan membuatnya melakukan apa yang tidak ingin dilakukannya, tetapi A juga menjalankan kekuasaan atas B dengan memengaruhi, membentuk, dan menentukan preferensi atau keinginannya sendiri (Lukes, 1974: 23). Di sini kekuasaan berupa konstruksi atau tatanan yang tak terlihat, nir-material dan halus (soft). Kekuasaan yang mengarah kepada kekuatan ideasional atau ideologi ini memiliki peran penting untuk dimainkan dalam membentuk tindakan politik dan menjalankan kekuatan persuasi dalam debat politik. Untuk itu idea perlu diwacanakan dan dinarasikan yang kemudian dikomunikasikan dan disebarkan ke masyarakat umum untuk diskusi dan musyawarah (dibuat menarik yang menarget hati dan pikiran target).

Dimensi ketiga kekuasaan ideasional yang ditawarkan oleh Lukes ini membuka ruang bagi diskusi dan perdebatan panjang mengenai kekuasaan-kekuasaan yang termasuk di dalamnya, seperti kekuasaan naratif, kekuasaan wacana dan soft power, maupun kekuasaan ekonomi perhatian (political economy of attention). Meskipun hasilnya satu kekuasaan dapat tereliminasi dan terlempar ke dalam satu dimensi kekuasaan yang lain dan baru, namun di antara kekuasaankekuasaan ideasional (ideational) yang bersifat halus dan tak kentara ini memiliki sesuatu yang saling mengaitkan satu sama lain, khususnya adalah narasi sebagai benang merahnya. 
Menurut Burke (1969) yang dikutip oleh Chang (2020) narasi adalah struktur tertentu yang terdiri dari aktor dan peristiwa, plot dan waktu, serta latar dan ruang. Plot antara adalah ide-ide, baik faktual maupun normatif dan fiktif. Ide merupakan substansi atau konten dari narasi. Melalui narasi yang sedemikian rupa ide mendapatkan kekuatannya. Narasi tidak ada tanpa ide. Oleh karena itu ide dan narasi dibangun bersama, memperkuat dan terjalin erat. Narasi berperan tidak hanya sebagai pembawa untuk menyampaikan dan mempresentasikan ide tetapi juga sebagai 'filter' untuk membumbui, menafsirkan, dan mempromosikan ide (Chang, 2020).

Kaitannya dengan kekuasaan wacana, dalam pengertian yang lebih luas, wacana merupakan bagian (interaktif) dari narasi. Narasi merupakan salah satu sarana wacana ekspresif yang digunakan untuk memaknai bersama suatu fenomena di antara sekelompok orang. Narasi antara lain menekankan bagaimana aktor menceritakan sebuah kisah yang berpusat pada diri sendiri. Wacana memiliki pengaruh penataan pada aksi naratif. Aktor secara refleks bekerja dengan wacana untuk membangun narasi dengan tujuan instrumental untuk mempengaruhi opini dan perilaku orang lain. Singkatnya, narasi menyempurnakan atau memproses kembali wacana ide dan wacana memberdayakan narasi menjadi berpengaruh. Keberhasilan dari narasi bila ide yang dikandung mampu melakukan transformasi dan membangun kepercayaan dan keyakinan individu maupun kolektif individu (para aktor) menjadi pandangan dunia, keyakinan berprinsip, dan keyakinan kausal, yang selanjutnya narasi ideasional tersebut menjadi sumber, dasar dan bimbingan bagi strategi negara dalam membuat kebijakan, program, dan tindakan serta membangun identitas kolektif (Chang, 2020).

Mengenai wacana, Michel Foucault (1972) mengatakan bahwa bahwa tidak ada wacanawacana yang membentuk pengetahuan bebas dari kekuasaan. Akan tetapi bukan kekuasaan yang membebani dengan pembatasan-pembatasan dan represif. Melainkan, kekuasaan sebagai proses jaringan relasional dan produktif yang mampu melintasi dan menghasilkan sesuatu, menimbulkan kesenangan, menghasilkan wacana dan bentuk pengetahuan, di seluruh tubuh sosial dalam produksi kebenaran dan rasionalitas. Struktur wacana sebagai pengetahuan tidak hanya mendeskripsikan dunia 'apa adanya', tetapi membangun dan membentuk cara pandangnya. Kebenaran dalam pengertian ini tidak dapat ditemukan secara objektif, tetapi merupakan efek wacana sebagai 'praktik yang secara sistematis membentuk objek yang mereka bicarakan'. Oleh karena itu hubungan kekuasaan tidak berarti hubungan yang dapat dilakukan oleh pihak-pihak yang 'memiliki' kekuasaan atas mereka yang tidak. Sebaliknya, mereka berjalan melalui semua 
hubungan sosial yang tersebar dan kontingen yang melaluinya sistem pengetahuan dan praktik wacana diproduksi, yang pada gilirannya merupakan agen dengan memberi mereka makna dan identitas. Batasan-batasan dari Foucault ini membawa kekuasaan wacana atau power/knowledge pada dimensi kekuasaan keempat dan non-esensialis, khususnya yang tidak memperlakukan kekuasaan hanya sebagai represif dan juga tidak dipahami dalam pengertian materi atau kelembagaan yang sederhana (Haugaard, 2018).

Dalam kaitannya dengan soft power, narasi dapat merupakan salah satu sumber dari soft power seperti yang dikemukakan oleh Joseph S Nye, Jr. (2004). Melaluinya, sumber-sumber budaya, kebijakan luar negeri dan nilai-nilai politik dinarasikan secara menarik dan diubah kapasitasnya sebagai kekuatan politik untuk membentuk preferensi, sikap dan perilaku jangka panjang pihak lain dan menjadikannya sebagai pengikut suka rela yang setia. Narasi strategis sebagai sebagai sumber kekuatan halus, nir-material, tanpa paksaan dan nir-koersif (soft power), sama pentingnya dengan sumber kekuasaan material (hard power) berperan untuk membuat ide yang diwacanakan itu memiliki daya kemenarikan (attractive power) yang mampu menyasar hati dan pikiran target (Nye J. S., 2004) dalam mencapai hasil berupa reputasi, citra dan legitimasi di dalam panggung internasional.

Dalam kaitannya dengan kekuasaan ekonomi politik perhatian, terutama ketika urusan internasional telah menjadi masalah 'cerita (narasi) siapa yang menang (Nye J. S., 2014). Kemenangan naratif diukur dari perolehan jumlah perhatian khalayak. Perhatian konsumen telah menjadi “barang modal atau 'komoditas' yang menekankan pada kognitif dan efek dari strategi informasi dalam membentuk identitas siap pasar, dan mereduksi ranah publik menjadi serangkaian pilihan tanpa akhir. Untuk memastikan kekuasaan aktor atas perhatian yang telah menjadi sumber daya ekonomi yang substansial untuk pembangunan persepsi dan pengambilan keputusannya, secara berketerusan naras-narasi menarik diproduksi dan ditampilkan aktor sebagai informasi subjektif yang mampu mendapatkan perhatian (Doran, 2017).

Di antara kelimpahan informasi sejak revolusi teknologi informasi pada abad ke-21 yang justru menciptakan kemiskinan perhatian, dan mengingat pula kemampuan perhatian manusia yang terbatas, diperlukan mekanisme atau sarana untuk menyusun, membentuk dan mengarahkan perhatian-perhatian. Untuk mengalokasikan perhatian-perhatian secara efisien dan mencapai tingkat popularitas dan viral di kalangan konsumen narasi-narasi subjektif perlu ditampilkaan secara menarik yang mengandung kiat-kiat dan unsur-unsur kemenarikan kekuasaan selebritas dan 
kekuasaan performatif (Rahman, 2014). Kemenarikan yang memancing perhatian bagaimanapun mengacu pada narasi atau wacana utama yang telah terendapkan atau dilembagakan agar tampak masuk akal dan diterima oleh khalayak target dan menjadi dominan. Secara bersamaan, narasi yang menarik perhatian itu harus mampu membangkitkan emosi dan citra pemerhati sehingga terjebak dalam narasi. Sejauh emosi tersebut terjalin dengan narasi yang sudah dominan, apa yang dilakukan narasi berpengaruh terhadap konsumen perhatian(Hagström \& Gustafsson, 2019).

Dalam studi HI arus utama narator adalah negara, pembuat kebijakan, atau praktisi politik internasional eksplisit lainnya. Sementara para penstudi atau sarjana (scholar) diakui bukan sebagai narator tetapi sebagai penyampai informasi dan analisis yang netral, objektif dan seimbang. Padahal dalam realitasnya mereka melalui penelitian dan tulisannya terlibat dalam membangun, mengulangi, dan menyebarkan narasi ketika mereka masih menggunakan paradigma (yang berisi perspektif, teori, konsep dan metode tertentu) yang merupakan struktur diskursif yang telah mendapat kesepakatan komunitas epistemik sebagai ilmu normal (normal science) (Kuhn, 1962). Dengan demikian seperti proses relasi kekuasaan knowledge/power dari Foucault para penstudi/sarjana sama halnya dengan semua aktor sosial, adalah produk narasi dan juga produser narasi atau narator. Lebih dari itu, mereka juga bertindak sebagai wirausaha naratif. Dalam kapasitas itu, seperti yang dikatakan oleh Hagström \& Gustafsson, mereka dapat mendukung narasi yang dominan atau berusaha membangun kontra-narasi sebagai suatu konstruksi narasi alternatif dan baru meskipun belum tentu mendapat perhatian dan diterima khalayak.

Dalam e-jurnal INTERMESTIC: Journal of International Relations Volume 5 Nomor 1 pada November 2020, kami menampilkan beberapa narasi berbentuk artikel akademik dari para narator sebagai penstudi maupun sarjana yang berkontribusi sehingga jurnal kami dapat terbit pada waktunya. Terima kasih kami sampaikan kepada para narator beserta judul artikelnya, sebagai berikut: "Peran Negara dalam Ekspansi PT Wijaya Karya Tbk. Ke Afrika" oleh Anggi Mariatulkubtia Lubis; "Analyzing Patriarchy, Political Participation, and Active Citizenship in ASEAN" oleh Anak Agung Mia Intentilia; "Globalisasi dan Pembangunan Infrastruktur Maritim Indonesia di Bidang Konektivitas dan Sistem Logistik (2014-2019)" oleh Fachri Pramuja dan Fredy Buhama L. Tobing ; "Diplomasi Ekonomi Indonesia sebagai Negara Middle Power di Rezim Ekonomi G20 Masa Pemerintahan Joko Widodo" oleh Wiwiek Rukmi Dwi Astuti dan Laode Muhamad Fathun; "Efek Destinasi Pariwisata terhadap Jumlah Kunjungan Wisatawan Mancanegara Ke Asia" olah Agita Arrasy Asthu; "Praktik Keamanan Manusia Soka Gakkai 
International di Indonesia, Filipina, dan Singapura ketika Pandemi Covid-19" oleh Muhammad Fikry Anshori dan Susy Ong; "Keruntuhan Rezim Evo Morales di Bolivia" oleh Muhaimin Zulhair Achsin; dan "Rasionalisasi Ekonomi Politik Lingkungan dalam EU-Japan Economic Partnership Agreement (EU-JEPA)” oleh Rafsyanjani Mohammad.

Bersamaan dengan publikasi e-jurnal kali ini, kami juga menghaturkan ucapan terima kasih tak terhingga atas kesediaan penelaah sejawat atau mitra bestari (peer reviewer), yaitu: Laode Muhamad Fathun, Ian Montratama, Bunga Aprillia, Viani Puspita Sari, Vinsensio Marselino Arifin Dugis, dan T. Rezasyah. Dengan kepakaran ilmu masing-masing dan konsentrasi khususnya akan memperkuat kualitas, kredibilitas serta posisi dan arah jurnal ini.

Hormat kami,

Arry Bainus dan Junita Budi Rachman

Pimpinan Redaksi dan Wakil Pimpinan Redaksi

\section{Referensi}

Allen, A. (1999). The power of feminist theory: domination, resistance, solidarity. Boulder: CO: Westview.

Bachrach, P., \& Baratz, M. S. (1962, December). Two Faces of Power. The American Political Science Review(4), 947-952.

Burke, K. (1969). A Rhetoric of Motives. Berkeley: University of California Press.

Chang, Y.-Y. (2020). The Post-Pandemic World: between Constitutionalized and Authoritarian Orders - China's Narrative-Power Play in the Pandemic Era, . Journal of Chinese Political Science. doi: https://doi.org/10.1007/s11366-020-09695-3

Dahl, R. A. (1961). Who governs: Democracy and power in an American city. New Haven, CT: Yale University Press .

Doran, P. (2017). A Political Economy of Attention, Mindfulness and Consumerism. Reclaiming the Mindful Commons. London: Routledge.

Engel, P. (Ed.). (2016, September 19). White House press secretary: We're in a 'narrative fight' with ISIS. Retrieved October 20, 2020, from Businessinsider: https://www.businessinsider.com/josh-earnest-narrative-fight-with-isis-20169? $\mathrm{r}=\mathrm{US} \& \mathrm{IR}=\mathrm{T}$

Foucault, M. (1972). Power/knowledge: selected interviews and other writings. London: Harvester Press.

Gilpin, R. (1981). War and change in world politics. Cambridge: Cambridge University Press.

Gustafsson, K., \& Hanssen, L. H. (2019). Long live pacifism! Narrative power and Japan's pacifist model. Cambridge Review of International Affairs,, 42(4), 502-520,. doi:10.1080/09557571.2019.1623174 
Hagström, L., \& Gustafsson, K. (2019). Narrative power: how storytelling shapes East Asian international politics. Cambridge Review of International Affairs, 32(4), 387-406. doi:DOI: 10.1080/09557571.2019.1623498

Haugaard, M. (2018). Justification and the four dimensions of power,. Journal of Political Power, 1-22. doi:10.1080/2158379X.2018.1433759

Hutchings, S., \& Szostek, J. (2015, April 28). Dominant Narratives in Russian Political and Media. doi:https://www.e-ir.info/2015/04/28/dominant-narratives-in-russian-politicaland-media-discourse-during-the-crisis/

Keohane, R. O., \& Nye, J. S. (1977). Power and interdependence: world politics in transition. Boston: Little, Brown.

Kuhn, T. S. (1962). The Structure of Scientific Revolutions. Chicago: University of Chicago Press, 1962. ISBN 0-226-45808-3. Chicago: Chicago Press.

Lukes, S. (1974). Power: A Radical View ed. (1 ed.). London: Macmillan.

Morgenthau, H. J. (1948). Politics among nations: the struggle for peace and power. New York: A.A. Knopf).

Nye, J. S. (2004). Soft Power : the Means to Success in World Politics. . New York: Public Affairs.

Nye, J. S. (2012). Power: Hard, Soft, and Smart. The Encyclopedia of Peace Psychology, (Vol. 1st). (D. J. Christie, Ed.) New York: Blackwell Publishing Ltd.

Nye, J. S. (2014, January). The Information Revolution and Soft Power. Current History, 113(759), 19-22. Retrieved from Current History: http://www.currenthistory.com/Article.php?ID=1113

Rahman, J. (2014). Kuasa Insaniah Negara Malaysia dan Imej-imej Selebriti Tun Dr. Mahathir Mohamad .

Ringmar, E. (1996). On the Ontological Status of the State. European Journal of International Relations , 439. doi:10.1177/1354066196002004002

Suganami, H. (2008). Narrative explanation and international relations: back to basic. Millennium: Journal of International Studies, 37(2), 327-356. doi:10.1177/0305829808097643

Szostek, S. H. (2015, April 28). Dominant Narratives in Russian Political and Media Discourse during the Ukraine Crisis. E-IR. doi:https://www.e-ir.info/2015/04/28/dominantnarratives-in-russian-political-and-media-discourse-during-the-crisis/ 